\title{
On Monotony of Opera Playbill and Underlying Economy
}

Elena Khokhlova / 403149@mail.muni.cz

Department of Musicology, Faculty of Arts, Masaryk University, Brno, CZ

\begin{abstract}
The study explores modern opera theater repertoires and focuses on the strategy of opera offering. Statistics and data analysis reveal strong tendencies of monotony, sameness, and repetitiveness of repertoire across the biggest and most productive opera houses in the world. The two ongoing tendencies are that the majority of opera theaters resort to reproducing a shortlist of canonized masterpieces and that there are hardly any new works presented onstage since the middle of the $20^{\text {th }}$ century.

Opera is possibly the most complex art form that demands not only immense resources and skills from its producers but also incredible attention and loyalty from the consumers. Complexity and demanding nature of this art form is certainly amongst the shaping factors of modern opera economy. But do constant reproduction of monotonous repertoire and recycling of the same opera titles have ulterior motives?
\end{abstract}

\section{Keywords}

opera production, playbill, repertoire, revival, remake, opera economy, audience 
What if theaters across the world were to limit their playbill offer to a tiny number of famous classics and resort to reproducing and recycling these titles from season to season? The repertoire would probably shrink to a mixture of Shakespeares, a Sophocles, a pair of Chekhovs and Moliers, spiced up by more modern Bernard Shaw and Tennessee Williams. And what if there mainly were but the same plays constantly produced, the titles relaying on theater posters and billboards all over the world for decades?

Yet Theater Communication Group's annual statistics based on American non-forprofit "straight" theater repertoires reveals that the lists of the most performed titles significantly differ from year to year. ${ }^{1}$ It does not mean that there are no rotating plays in theater repertoire. In fact, Shakespeare's plays alone top the list on the regular basis. ${ }^{2}$ But the classics hardly represent the backbone in this industry, leaving space for flexible repertoire renewal and update. ${ }^{3}$

Now, a mere glance at a random opera playbill is enough to spot the rotation of familiar titles and very little number of famous composers present in it. Interestingly, throughout the $17^{\text {th }}$ and $18^{\text {th }}$ centuries "almost all opera was new [...] Revivals might occur, but it was more prestigious to have a brand-new work". ${ }^{4}$ From today's perspective though, the vast majority of staged operas across the globe are revivals or remakes. For a tradition that is older than 400 years one would expect that opera has a monstrous list of works to make a busy playbill that changes every season. And it does, yet only a limited number of those is produced.

\section{Observations and Data}

Once a proud presenter of luxurious inflow of new work every year, modern opera industry seems rather stagnant. A certain list of operatic titles is familiar not only to the regular opera audience but even to the opera outsiders. In fact, those who do not attend operas often know about the existence of such works as Tosca, Madama Butterfly, or Car-

1 TRAN, Diep. The Top 10 Most-Produced Plays of the 2017-18 Season. URL: https://www.americantheatre. org/2017/09/21/the-top-10-most-produced-plays-of-the-2017-18-season/ [retrieved 1-Apr-2018]; TRAN, Diep. The Top 10* Most-Produced Plays of the 2016-17. URL: https://www.americantheatre.org/2016/09/21/the-top10-most-produced-plays-of-the-2016-17-season/ [retrieved 1-Apr-2018]; TRAN, Diep. The Top 10 Most-Produced Plays of the 2015-16 Season. URL: https://www.americantheatre.org/2015/09/16/the-top-10-most-producedplays-of-the-2015-16-season/ [retrieved 1-Apr-2018]; TRAN, Diep. The Top 10 Most-Produced Plays of the 2014-15 Season. URL: https://www.americantheatre.org/2014/09/23/top-10-plays-2014-2015/ [retrieved 1-Apr-2018]

2 TRAN, Diep. The Top 10 Most-Produced Plays of the 2017-18 Season - American Theater. A Publication of Theater Communications Group. URL: https://www.americantheatre.org/2017/09/21/the-top-10-most-produced-plays-of-the-2017-18-season/ [retrieved 1-Apr-2018]

3 This finding is also backed up by Analysis of Theatre in English by Art Council England demonstrating that by the year 2013 theater repertoire consists of approximately $60 \%$ of new work versus revivals while new plays account for over $50 \%$ in repertoire of straight theater - Final Report by BOP Consulting \& Graham Devlin Associates, 13th September - 2016, p. 41. URL: http://www.artscouncil.org.uk/sites/default/files/download-file/Analysis\%20of\%20Theatre\%20in\%20England\%20-\%20Final\%20Report.pdf [retrieved 7-Apr-2018]

4 ABBATE, C. Parker, R. A History of Opera. The Last 400 Years. Penguin Books, 2015, p. 521. 
men. It happens either because this outside audience was once forced to an opera house to see an obligatory La Traviata or due to constant exposure to posters, billboards, announcements, flyers, and other urban opera advertisement which flashes the titles every season.

According to the Operabase statistics that gathers data from around the world ("over 25.000 performances of opera every year" ${ }^{\prime \prime}$ ) the same composers and the same titles have been dominating the top 10 most performed operas in the past five seasons (2010/2011 through 2015/2016). The listing in Table 1 is based on the latest data gathered from 116730 performances of over than 900 opera companies within the five seasons between 2011/2012 and 2015/2016:

\begin{tabular}{|r|r|l|l|l|r|r|}
\hline $\begin{array}{c}\text { Global } \\
\text { ranking }\end{array}$ & $\begin{array}{r}\text { Ranking in } \\
\mathbf{2 0 1 5 / 2 0 1 6}\end{array}$ & $\begin{array}{c}\text { National } \\
\text { ranking }\end{array}$ & \multicolumn{1}{|c|}{ Composer } & \multicolumn{1}{|c|}{ Work } & $\begin{array}{c}\text { \# of perfor- } \\
\text { mances }\end{array}$ & $\begin{array}{c}\text { \# of produc- } \\
\text { tions }\end{array}$ \\
\hline 1 & $\mathbf{1}$ & it (\#1) & Verdi (\#1) & La traviata & 4190 & 869 \\
\hline 2 & $\mathbf{2}$ & at (\#1) & Mozart (\#1) & Die Zauberflote & 3310 & 561 \\
\hline 3 & $\mathbf{3}$ & $\mathbf{f r}(\# 1)$ & Bizet (\#1) & Carmen & 3280 & 691 \\
\hline 4 & $\mathbf{4}$ & it (\#2) & Puccini (\#1) & La bohéme & 3131 & 672 \\
\hline 5 & $\mathbf{5}$ & it (\#3) & Puccini (\#2) & Tosca & 2694 & 608 \\
\hline 6 & $\mathbf{6}$ & it (\#4) & Puccini (\#3) & Madama Butterfly & 2641 & 634 \\
\hline 7 & $\mathbf{7}$ & it (\#5) & Rossini (\#1) & Il barbiere di Siviglia & 2549 & 591 \\
\hline 8 & $\mathbf{8}$ & at (\#2) & Mozart (\#2) & Le nozze di Figaro & 2483 & 545 \\
\hline 9 & $\mathbf{9}$ & at (\#3) & Mozart (\#3) & Don Giovanni & 2299 & 473 \\
\hline 10 & $\mathbf{1 0}$ & it (\#6) & Verdi (\#2) & Rigoletto & 2285 & 523 \\
\hline
\end{tabular}

Table 1. The most performed composers and their operatic works, 2011 through $2016^{6}$

These ten operas (out of 2658 listed in the database) cover 28862 out of 116730 performances and 6167 out of 26984 productions. It means that only $0.37 \%$ of opera titles account for $24.7 \%$ of all opera performances and $22.8 \%$ of all opera productions in the range.

The fact that the global ranking here corresponds with seasonal and national ratings pinpoints the tendency of modern opera playbills to be repetitive and monotonous. To be more consistent I compared this data with the most recent season $(2017 / 2018)$ of the most productive opera companies in the world. In order to create the representative group I have selected the largest and most influential opera houses that are based in the countries (and selected cities) with the highest opera production density in season 2015/2016, as per Operabase ${ }^{7}$ (see Tables 2 and 3).

5 Operabase. URL: http://operabase.com/index.cgi?lang=en [retrieved 2-Apr-2018]

6 The table is copied from the Operabase. URL: http://operabase.com/top.cgi?lang=en\&break=0\&show=oper $\mathrm{a} \& \mathrm{no}=10 \& \mathrm{cnat}=[$ retrieved 1-Apr-2018]

7 Operabase. URL: http://operabase.com/top.cgi?lang=en\&splash=t [retrieved 30-Mar-2018] 


\begin{tabular}{|r|l|r|}
\hline Ranking in 2015/2016 & Country & \# of productions in country \\
\hline $\mathbf{1}$ & Germany & 6795 \\
\hline $\mathbf{2}$ & United States & 1657 \\
\hline $\mathbf{3}$ & Russia & 1490 \\
\hline $\mathbf{4}$ & Italy & 1393 \\
\hline $\mathbf{5}$ & Austria & 1163 \\
\hline $\mathbf{6}$ & France & 1020 \\
\hline $\mathbf{7}$ & United Kingdom & 989 \\
\hline $\mathbf{8}$ & Czech Republic & 818 \\
\hline
\end{tabular}

Table 2. Leading countries in number of opera productions in season $2015 / 2016$, as per Operabase ${ }^{8}$

\begin{tabular}{|r|l|l|r|}
\hline Ranking per production density & Ranking in the country & City & \# of productions in city \\
\hline $\mathbf{1}$ & ru $(\# 1)$ & Moscow & 582 \\
\hline $\mathbf{2}$ & at $(\# 1)$ & Wien & 535 \\
\hline $\mathbf{3}$ & de $(\# 1)$ & Berlin & 527 \\
\hline $\mathbf{4}$ & uk $(\# 1)$ & London & 427 \\
\hline $\mathbf{7}$ & $\mathbf{c z}(\# 1)$ & Praha & 357 \\
\hline $\mathbf{9}$ & us $(\# 1)$ & New York & 284 \\
\hline $\mathbf{1 1}$ & $\mathbf{f r}(\# 1)$ & Paris & 245 \\
\hline $\mathbf{2 2}$ & it $(\# 1)$ & Venezia & 139 \\
\hline
\end{tabular}

Table 3. Representative cities in leading countries in season $2015 / 2016$, as per Operabase 9

I have sourced the opera productions and the number of separate operatic titles by the same composer presented in the season from the official opera houses web-pages. The tables below represent which and how many of the world most performed titles are included in the representative houses' playbill in seasons 2017/2018 and 2018/2019 (if available - unfortunately, not all the opera companies announced their upcoming season by the time of conducting this study). Empty cells mean that the title is not present in the season repertoire, while "No data" stands for no published information about the upcoming season.

8 The table is taken from Operabase. URL: http://operabase.com/top.cgi?lang=en\&break=0\&show=natio n\&no=10 [retrieved 1-Apr-2018]

9 The table is taken from Operabase. URL: http://operabase.com/top.cgi?lang=en\&break=0\&show=loc\&n $\mathrm{o}=10 \&$ nat $=$ [retrieved 2-Apr-2018] 


\begin{tabular}{|c|c|c|c|c|c|c|c|c|c|c|}
\hline Season $2017 / 2018$ & 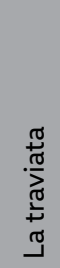 & 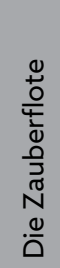 & 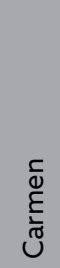 & 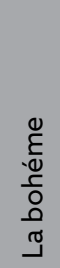 & $\begin{array}{l}\text { ్ֶ } \\
\stackrel{\rho}{\circ}\end{array}$ & 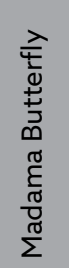 & 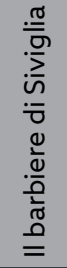 & 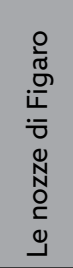 & 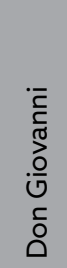 & $\begin{array}{l}\stackrel{0}{ \pm} \\
\frac{0}{0} \\
\frac{0}{0} \\
\frac{\sigma}{\alpha}\end{array}$ \\
\hline Bolshoi Theater of Russia (ru) & Yes & & Yes & Yes & & & & Yes & & \\
\hline Teatro la Fenice (it) & Yes & & & Yes & & Yes & Yes & & & \\
\hline Prague National Theater (cz) & Yes & Yes & Yes & & Yes & Yes & Yes & Yes & Yes & \\
\hline Wiener Staatsoper (at) & Yes & Yes & Yes & Yes & Yes & Yes & Yes & Yes & Yes & Yes \\
\hline Royal Opera House (uk) & & Yes & Yes & Yes & Yes & & & & Yes & Yes \\
\hline Metropolitan Opera (us) & & Yes & & Yes & Yes & Yes & Yes & Yes & & \\
\hline Opéra national de Paris (fr) & Yes & & & Yes & & & Yes & & & \\
\hline Deutsche Oper Berlin (de) & Yes & Yes & Yes & Yes & Yes & Yes & Yes & Yes & Yes & Yes \\
\hline
\end{tabular}

Table 4. Inclusion of the most performed opera titles in the biggest world theaters' playbills (season 2017/2018)

\begin{tabular}{|c|c|c|c|c|c|c|c|c|c|c|}
\hline $2018 / 2019$ & 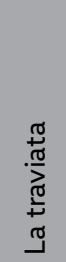 & 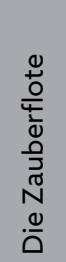 & 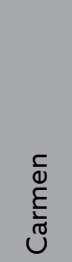 & 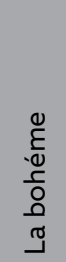 & $\begin{array}{l}\text { đ్ } \\
\stackrel{్}{\circ}\end{array}$ & 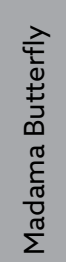 & 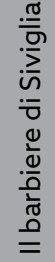 & 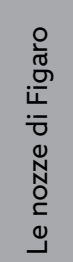 & 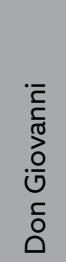 & $\begin{array}{l}\frac{0}{ \pm} \\
\frac{0}{0} \\
\frac{0}{\alpha} \\
\frac{\sigma}{\alpha}\end{array}$ \\
\hline Bolshoi Theater of Russia (ru) & \multicolumn{10}{|c|}{ No data } \\
\hline Teatro la Fenice (it) & \multicolumn{10}{|c|}{ No data } \\
\hline Prague National Theater (cz) & Yes & Yes & Yes & Yes & Yes & Yes & & Yes & Yes & \\
\hline Wiener Staatsoper (at) & \multicolumn{10}{|c|}{ No data } \\
\hline Royal Opera House (uk) & Yes & & Yes & & Yes & & & Yes & & \\
\hline Metropolitan Opera (us) & Yes & Yes & Yes & Yes & Yes & & & & Yes & Yes \\
\hline Opéra national de Paris (fr) & Yes & Yes & Yes & & Yes & & & & Yes & \\
\hline Deutsche Oper Berlin (de) & \multicolumn{10}{|c|}{ No data } \\
\hline
\end{tabular}

Table 5. Inclusion of the most performed opera titles in the biggest world theaters' playbills (season 2018/2019)

Finally, I have counted the number of operatic titles authored by the most performed composers (see column "Composer" in Table 1) in the playbills of the named opera houses in each season. For example, the number 3 in the cross cell of Bolshoi and Verdi means that there are three different operatic titles by Verdi present in the repertoire of Bolshoi Theater in 2017/2018 (these are Don Carlo, La Traviata, and Un Ballo in Maschera in this particular case). 


\begin{tabular}{|l|r|r|r|r|r|}
\hline 2017/2018 & Verdi (\#1) & Mozart (\#2) & Bizet (\#3) & Puccini (\#4) & Rossini (\#5) \\
\hline Bolshoi Theater of Russia (ru) & 3 & 2 & 1 & 2 & 0 \\
\hline Teatro La Fenice (it) & 2 & 0 & 0 & 3 & 3 \\
\hline Prague National Theater (cz) & 5 & 5 & 1 & 3 & 2 \\
\hline Wiener Staatsoper (at) & 9 & 3 & 1 & 4 & 3 \\
\hline Royal Opera House (uk) & 4 & 2 & 2 & 2 & 1 \\
\hline Metropolitan Opera (us) & 3 & 4 & 0 & 4 & 1 \\
\hline Opéra national de Paris (fr) & 5 & 1 & 0 & 2 & 1 \\
\hline Deutsche Oper Berlin (de) & 7 & 5 & 1 & 4 & 2 \\
\hline
\end{tabular}

Table 6a. Number of original titles by the top performed composers that are included in the opera house repertoire (2017/2018)

\begin{tabular}{|c|c|c|c|c|c|}
\hline $2018 / 2019$ & Verdi $(\# 1)$ & Mozart (\#2) & Bizet (\#3) & Puccini (\#4) & Rossini (\#5) \\
\hline Bolshoi Theater of Russia (ru) & \multicolumn{5}{|l|}{ No data } \\
\hline Teatro la Fenice (it) & \multicolumn{5}{|l|}{ No data } \\
\hline Prague National Theater (cz) & 6 & 4 & 1 & 4 & 1 \\
\hline Wiener Staatsoper (at) & \multicolumn{5}{|l|}{ No data } \\
\hline Royal Opera House (uk) & 5 & 2 & 1 & 1 & 0 \\
\hline Metropolitan Opera (us) & 5 & 3 & 2 & 4 & 0 \\
\hline Opéra national de Paris (fr) & 4 & 2 & 1 & 1 & 1 \\
\hline Deutsche Oper Berlin (de) & \multicolumn{5}{|l|}{ No data } \\
\hline
\end{tabular}

Table 6b. Number of original titles by the top performed composers that are included in the opera house repertoire $(2018 / 2019)$

The data collected for the season 2017/2018 demonstrates that the most popular title choices amongst the eight representative theaters are La Bohéme (performed at 7 theaters out of 8; excluded from Prague National theater's playbill), La Traviata (6 out of 8 theaters perform it this season; exclusions are Royal Opera House and Metropolitan Opera), and Il Barbiere di Seviglia (also performed at 6 out of 8 theaters with the exclusion of Bolshoi and Royal Opera House). The least produced operatic work is Rigoletto; only Wiener Staatsoper, Deutsche Oper Berlin, and Royal Opera House included it in their current playbill.

The opera houses that closely follow the statistical pattern by staging the most performed operas this season are Wiener Staatsoper (10 out of 10 operas are performed), Deutsche Oper Berlin (10 out of 10 operas are performed), and Prague National Theater ( 8 out of 10 operas are performed). The houses that currently follow the pattern the least are Opéra national de Paris (only 3 out of 10 operas are in the current playbill), Teatro la Fenice and Moscow's Bolshoi Theater (only 4 titles are present in the current playbills in both cases).

There are five composers who authored the ten most performed operas and their count also emphasizes the trend (Table 7). For example, out of 54 different opera productions in the season 2017/2018 Wiener Staatsoper offered nine different works by Verdi (Aida, Un Ballo in Maschera, Falstaff, Macbeth, Otello, Rigoletto, Simon Boccane- 


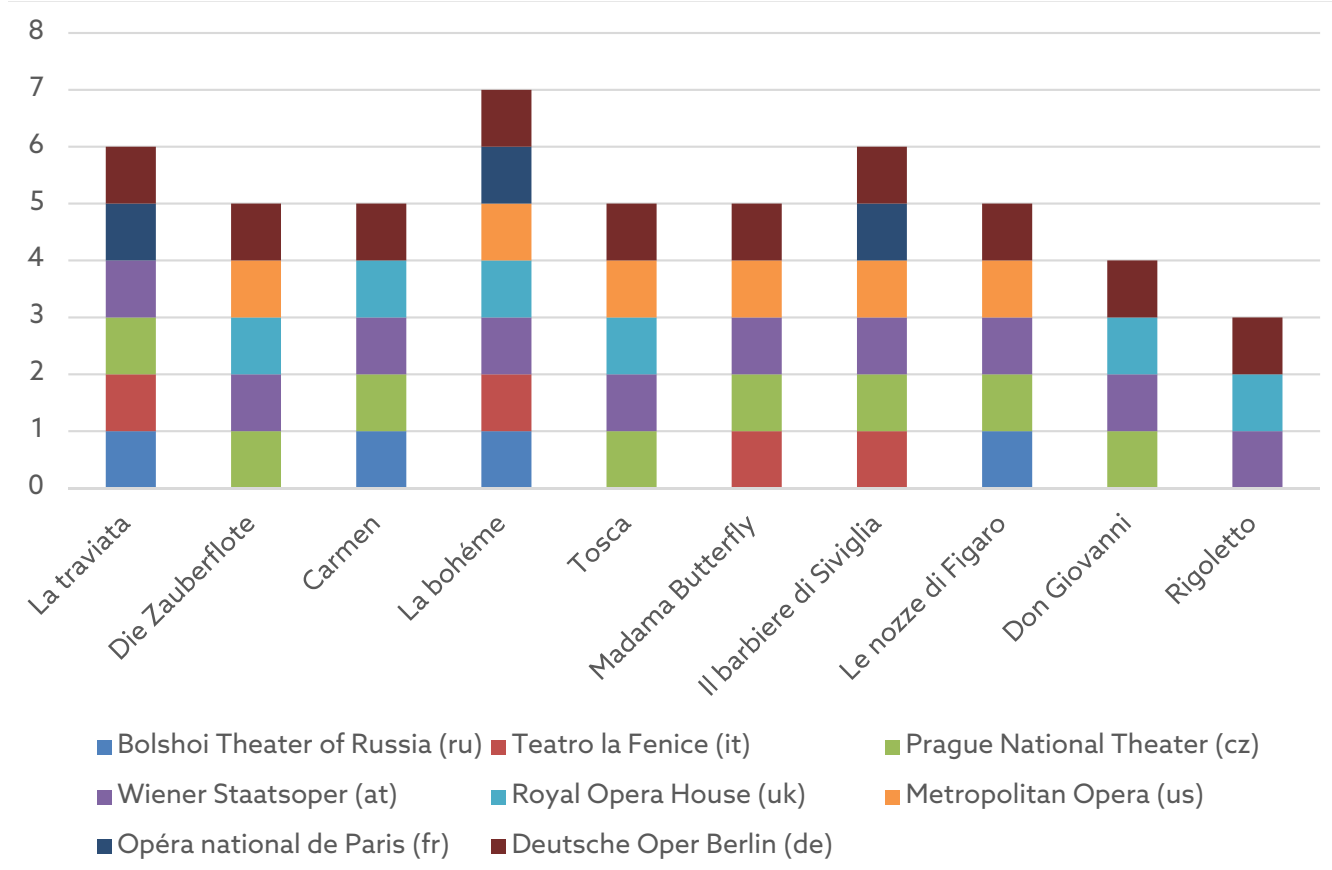

Table 7. Comparison of most performed opera titles in representative group of theaters in the season 2017/2018.

gra, La Traviata, and Il Trovatore). Verdi seems to be the first composer of choice for opera managers, for his distinctive works are present in the representative group of 8 theaters 38 times only in the current season. Out of the ten most performed world operas, Verdi's La Traviata appears in the playbills most of the time, and Rigoletto the least often. In considerable distance after Verdi there is Puccini with 24 different productions of his works only in the 8 theaters. La Bohéme is presented by 7 out of 8 theaters, and Tosca and Madama Butterfly follow closely being presented at 5 different theaters. The least performed composer of the top five is Bizet with only two of his works produced by the representative group (Carmen and Les pêcheurs de perles). Yet his Carmen is so popular that he gains the spot amongst the five most performed composers outpacing masters with such operatic prominence as Wagner, Tchaikovsky, Handel, or Donizetti.

The question is whether the tendency of producing and reproducing the selection of opera titles is due to the truly unique elevated level of aesthetical quality of these operatic works, if it is an audience revealed preference, or if there are other ulterior motives rooted in opera economy. I would like to explore the latter as an underlying crucial condition that defines pace and logic of production and promotion activities in opera industry. 


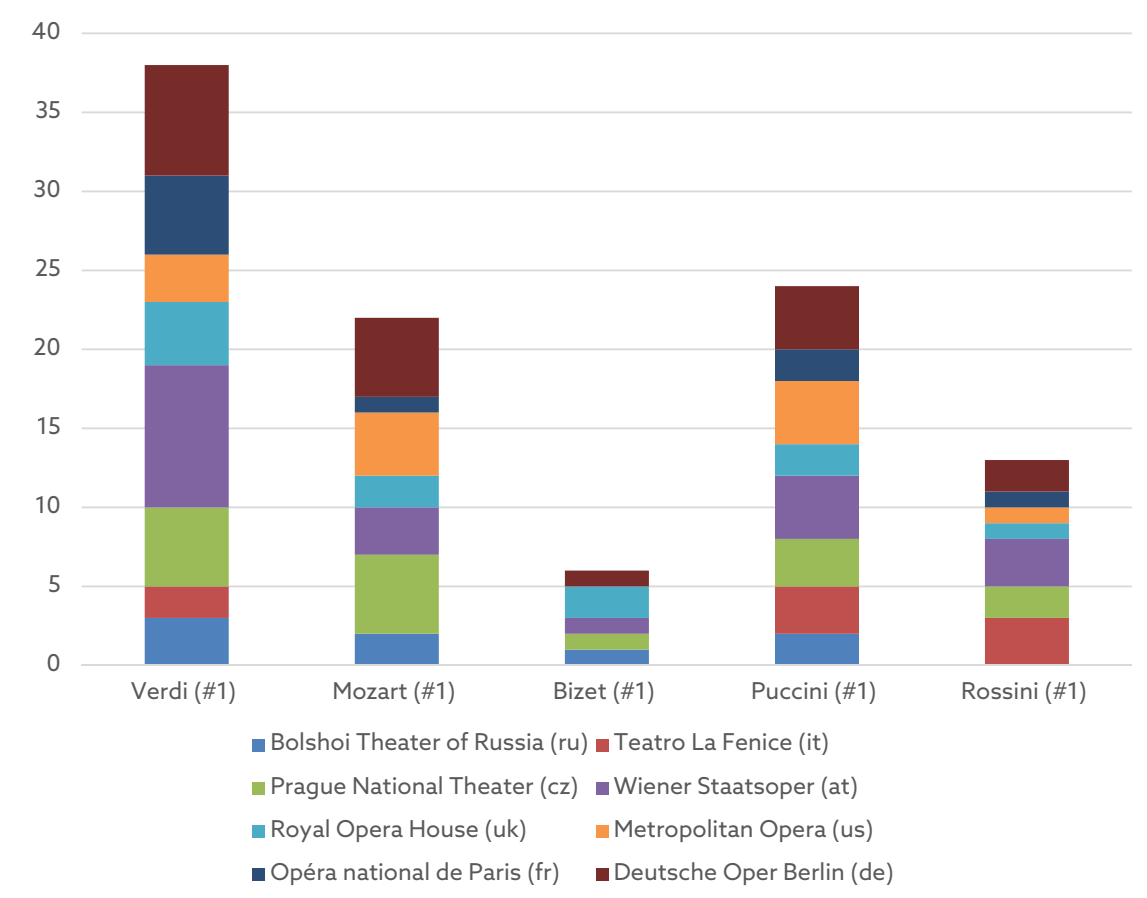

Table 8. Distinct operatic works per composer presented in $2017 / 2018$ season of the representative theaters.

\section{On Complexity of Mounting an Opera}

Opera could easily compete to be called the most sophisticated art form next to "straight" theater and cinema. A brisk glance at morphology of art reveals its complexity and intricacy. In his study Moses Kagan argues that there are fundamental or basic art forms, as well as "syncretic-synthetic" 10 ones which are constructed in combination and hybridization of the former ${ }^{11}$. Moreover, "there are three and only three possible dimensions that define the existence of an art form. There is the spatial dimension which is shared by visual arts, including such ones as graphics, sculpture, architecture and crafts; there is the temporal dimension typical for verbal and musical art forms; finally, there is the spatial-temporal dimension that characterizes acting and dance". ${ }^{12}$ To put it simply, there are "exclusively spatial art forms that are static, disconnected from temporal changes; exclusively temporal art forms that are processual, dynamic,

10 KAGAN, Moses. Morfologiya iskusstva. Istoriko-teoreticheskoye issledovaniye vnutrennego strojeniya mira iskusstv. Leningrad: Iskusstvo, 1972, p. 374.

11 Ibid, pp. 358-359.

12 KAGAN, Moses. Morfologiya iskusstva. Istoriko-teoreticheskoye issledovaniye vnutrennego strojeniya mira iskusstv. Leningrad: Iskusstvo, 1972, p. 374. 
disconnected from plastic materiality of spatial being; finally, there are those that unify in both of the latter, unfolding in time and space simultaneously". ${ }^{13}$

In this standpoint opera belongs to the most complexly structured synthetic art forms. In Kagan's retrospective opera is classified as a scenic type of complex arts with prevalence of non-descriptive or "graphic", non-mimetic expressive means, or languages which manifest the ideas not literally but abstractly ${ }^{14}$. With the obvious dominance of music as the underlying fundamental art defining the very nature of operatic work, opera also exploits literature in libretto, architecture in acoustic planning and decorations, visual design in stage and costume design, acting and pantomime in performance, etc. It also belongs to the group of temporal-spatial art forms, for it unfolds in both, time and space.

Finally, it is important to note that modern operatic staging employ even wider ranges of modern art form elements and technologies. For example, the most progressive opera directors integrate in producing their works such expressive means as holograms, ${ }^{15}$ video art, virtual reality, ${ }^{16}$ close-up capture, onstage manipulation with video, projecting, adapted subtitles, behind-the-stage walks, etc. Opera managers also reach for the aid of the Internet (live transmissions, online broadcast, virtual databases and archives available on subscription basis, presence and promotion in social networks, live red carpet footage, Twitter seats,${ }^{17}$ etc.), digitalization (HD recordings available in all modern data carriers and online), and other advantageous services in promoting and distributing the art. All these efforts demonstrate the level at which opera tries to stay relevant, modern and flexible in order to attract and seduce the audience at a larger scale. This transforms both, operatic product and its distribution making modern opera an absorbent synthesis of all-dimensional expressive means adopted from art forms related and not related to it.

Even in its original form 400 years ago opera already syncretized several expressive language systems creating a very complex, multi-layered expensive product. Back then opera industry used to be much more dynamic producing and presenting new titles each season $^{18}$. "Until about 1800, most operas were written for a specific season in a specific theater [...]; some works might be repeated [...] but they were generally expected to be supplanted by next

13 Ibid.

14 Ibid, pp. 388-389.

15 Christie Projectors Make The First Holographic Opera A Reality. URL: https://www.christiedigital.com/ emea/business/visual-solutions-case-studies/visual-solutions-application-stories/telesio-holographic-opera [retrieved 7-Apr-2018]

16 An example with a trailer can be found at University of Bath web-page: Latest Virtual Reality Technology Makes Opera Even More Magical. URL: http://www.bath.ac.uk/research/news/2017/10/11/vr-opera/ [retrieved 8-Apr-2018]

17 A questionable trend that came to American opera houses and symphony concerts in 2011 outlived the rumors and is still relevant, for example, at Opera Theatre of Saint Louis [https://www.opera-stl.org/exploreand-learn/for-everyone/2018-tweet-seats /], Palm Beach Opera [https://pbopera.org/currentseason/tickets/ tweet-seats/], Boston Lyric Opera [http://info.blo.org/figaro-tweet], and others.

18 See for example pre-repertoire opera description in ABBATE, C., Parker, R. A History of Opera. The Last 400 Years. Penguin Books, 2015, p. 22, 55. 
year's crop" ${ }^{19}$ According to the historians, only in the $19^{\text {th }}$ century the tradition of revivals was slowly established when several more successful (and probably more economically reasonable and frugal) titles from the previous centuries started getting in a regular repertory. Finally, "continued into the early twentieth century [...] at a certain point [...] the operatic repertory became primarily the matter of revivals and canonized work". ${ }^{20}$

While modern opera gets more complex and multilayered, the production diversity and pace gets more stagnant and inflexible. The standard repertoire consists of three groups of operatic works, $50 \%$ of all-time classics "also called "warhoreses", "evergreens", or "blockbusters", ${ }^{21} 30 \%$ of "possibles", or less famous, yet tested brands, and $20 \%$ of "rarities", either even less known and long-forgotten classics, or completely new modern or contemporary operas. ${ }^{22}$ The backbone of an opera repertoire consists of either revivals or remakes, and very rarely does it include completely new writing. ${ }^{23}$ The industry became more conservative and less open to experiments despite of the number of contemporary composers and their new writing. ${ }^{24}$ Despite of a small number of opera companies that present partially or exclusively contemporary operatic work, the statistics above reveal the tendency of the major opera companies to be predominantly rooted in the traditional logic of playbill management.

The reasons lay in the economy of modern opera industry. Each new opera production costs a pretty penny. For example, an average cost of a new production by The Metropolitan Opera was estimated at $\$ 2-\$ 3$ million in $2010^{25}$ and the six new productions in season $2015 / 2016$ accounted for $5 \%$ of total operating expenses in $2016 .{ }^{26}$ The more the new productions are designed and executed in contemporary sophisticated way, the more expressive means they employ, and the more performers and props they demand onstage and in the orchestra pit, the higher goes the expenditure number. After all, the whole repertoire opera concept seems to have spawned due to worsening financial situation and reoccurring budget holes: "the political disruptions of 1848-9 put many theaters into such financial difficulties that they were obliged to rely increasingly on revivals of past works [...]". ${ }^{27}$

In the meantime revivals are not only less expensive in the nature, but also more tested and reliable income sources. For example, English National Opera's production

19 Ibid, p. 32

20 Ibid.

21 AGID, P., TARONDEAU, J. The Management of Opera: An International Comparative Study. Palgrave Macmillan, 2010, p. 21.

22 Ibid.

23 Ibid, p. 33.

24 Operabase lists 664 living composers responsible for 2036 operatic productions between 2011 and 2016. URL: http:/ $/$ operabase.com/top.cgi?lang $=$ en\&break $=0 \&$ show $=$ alive\&no $=0 \&$ nat $=$ [retrieved 7-Apr-2018]

25 MUNK, Nina. The Met's Grand Gamble. URL: https://www.vanityfair.com/culture/2010/05/metropolitan-opera-201005 [retrieved 6-Apr-2018]

26 Considering that the fiscal year ended in July, 31, 2016 - The Metropolitan Opera Annual report 2015/2016. URL: https://www.metopera.org/metoperafiles/annual_reports/2016-17/AR1516.pdf [retrieved 6-Apr-2018]

27 ABBATE, C., Parker, R. A History of Opera. The Last 400 Years. Penguin Books, 2015, p. 190. 
of War and Peace of 2001 "has cost $£ 1,045,800$ to stage, including rehearsal and performance fees for singers, musicians and actors $(£ 581,300),{ }^{28}$ plus the costs of the directors, sets, props and costumes". ${ }^{29}$ Also in 2001 "Queen of Spades at the Royal Opera House, for example, had production costs of $£ 300,000$ and took $£ 656,300$ net at the box office [...] When the production comes back [next season], it will cost just £5,000, with maximum box office takings of £838,000”. ${ }^{30}$ Clearly, it is savier to fill in the repertoire with existing productions unless the opera house budget or donors' support allows to divest in remakes or even new works.

There are at least three ways tested works, or "blockbusters" and "rarities" are reproduced. They could be dragged from the archives and presented in the form of revivals. This is when an existing, premediated, fully designed production with ready decorations, props and costumes is mounted and re-ran. It happens most often in most of the opera theaters when a production stays onstage from one season to another. They could also be produced in cooperation with a partnering theater. The budget for staging in this case is collected from all the partners' pockets and the production is then shared between the theaters. For example, the most recent Cosi Fan Tutte at The Metropolitan Opera premiered in March 2018 is actually a co-production with English National Opera, which had staged the opera back in $2014 .{ }^{31}$ Finally, an operatic title that had already been staged and revived becomes outdated and less profitable. It then can be remade, in other words the old production is replaced by a new one. It is also the case of the said Cosi Fan Tutte at The Met, which took the place of a much older and far more traditional production from 1996.

Updating an old operatic title and investing in new productions is a step forward to making opera industry more relevant, flexible and up-to-date. However, it is very risky to divest into completely new (especially contemporary) titles with less established associated brand names (composers, librettists, performers, etc.). Opera companies that take such creative risk tend to balance their budget with a number of operatic "warhorses" that "reduce the risks for the whole repertoire, as the income they generate not only covers their direct costs but makes it possible to finance productions that are riskier or have a shorter performance life" ${ }^{32}$ Another reason to stick with the canonic titles in this perspective is to evade dramatic financial risks and ensure attendance and a smooth fiscal year.

Abbate \& Parker suggest, amongst other reasons, that opera repertoire turned to be self-preserved and stagnant also due to "anti-hedonism" of musical modernism exemplified by Schoenberg, ceasing of the main opera sponsor and requestor - the royalties and

28 The named cost equals approximately $\$ 1,703,213$ and the fee is estimated at $\$ 946,718$ nowadays.

29 HIGGINS, Charlotte. Why Is Opera So Expensive? URL: https://www.theguardian.com/culture/2001/ nov/29/artsfeatures2 [retrieved 30-Mar-2018]

30 These values are estimated in 2018 with consideration of inflation as follows: production costs $\$ 488,572$, net box office $\$ 1,068,833$, revival cost $\$ 8,145$, and box office estimation $\$ 1,365,026$; HIGGINS, Charlotte. Why Is Opera So Expensive? URL: https://www.theguardian.com/culture/2001/nov/29/artsfeatures2 [retrieved 30-Mar-2018]

31 Cosi Fan Tutte at The Metropolitan Opera. URL: https://www.metopera.org/season/2017-18-season/ cosi-fan-tutte-mozart-tickets/ [retrieved 7-Apr-2018]

32 AGID, P., TARONDEAU, J. The Management of Opera: An International Comparative Study. Palgrave Macmillan, 2010, p. 66 . 
aristocracy - and general unpredictability of success of the new writing. ${ }^{33}$ It is true that in the current economy opera companies can only rely on their current sponsors - the state (in most cases) providing subsidies, the donors contributing with sponsorship and gifts, and the audience attendance ensuring box office sales. There are additional strategies to raise budget, for example via subscriptions, On Demand programs, merchandise, gala events, and others, but this is a subject for another study.

The trend of sameness in operatic choices that creates monotonous playbills saves time and recourses for the opera companies that are overwhelmed by the costs and risks of new productions. Concealing the monotony of opera offering is possible by refreshing aging productions, shifting performers, sourcing productions from far-distanced partners, creating additional material around the productions, and, of course, including a new title in the playbill every now and then at all costs. Revival trend visually present in the opera industry is a way to save on operational expenses and yet deliver the product to the audience on the regular basis.

\section{Afterword}

The ulterior motives that determine opera economy are only one side to look at when solving the puzzle of the repertoire monotony. Audience perception is another one. Although, it forms part of the economy by creating attendance, it is also the most important party being the art recipient. There are certain musicology, psychology, and neuroscience studies that could explain the necessity of rotating titles in the opera repertoires. Modern information overload, massive pressure from entertaining industries and their war on customers' attention, raising rates of attention deficit disorder, fading abilities of focusing and raising demand of constant multitasking set new requirements on opera product from the perspective of its tired audience.

Once again, opera, possibly the most complex art form, is very demanding for the perceiving party. But the demand and complexity has to be amended in order for the industry to keep the audience in the house. Recycling the operatic "blockbusters" could actually be a solution, since some musicology and most neuroscience theories prove that the familiar is more pleasant, enjoyable, and comfortable than the new, in both, auditory and visual senses. After all even the mainstream cinema industry had resorted to recycling and elaborating on existing stories. Modern movie blockbusters are more often than not remakes, sequels or prequels. It could be that opera industry has been employing a similar strategy to keep the audience comfortable and entertained all along.

33 ABBATE, C., Parker, R. A History of Opera. The Last 400 Years. Penguin Books, 2015, p. 523. 


\section{Bibliography}

ABBATE, C. Parker, R. A History of Opera. The Last 400 Years. Penguin Books, 2015, 656 p.

AGID, P., TRONDEAU, J. The Management of Opera: An International Comparative Study. Palgrave Macmillan, 2010, $300 \mathrm{p}$.

Christie Projectors Make The First Holographic Opera A Reality. URL: https://www.christiedigital. com/emea/business/visual-solutions-case-studies/visual-solutions-application-stories/telesioholographic-opera [retrieved 7-Apr-2018]

Cosi Fan Tutte at The Metropolitan Opera. URL: https://www.metopera.org/season/2017-18-season/cosi-fan-tutte-mozart-tickets/ [retrieved 7-Apr-2018]

Final Report by BOP Consulting Ev Graham Devlin Associates, 13th September - 2016, p. 41. URL: http://www.artscouncil.org.uk/sites/default/files/download-file/Analysis\%20of\%20Theatre\%20in\%20England\%20-\%20Final\%20Report.pdf [retrieved 7-Apr-2018]

HIGGINS, Charlotte. Why Is Opera So Expensive? - URL: https://www.theguardian.com/culture/2001/nov/29/artsfeatures2 [retrieved 30-Mar-2018]

KAGAN, Moses. Morfologiya iskusstva. Istoriko-teoreticheskoye issledovaniye vnutrennego strojeniya mira iskusstv. Leningrad: Iskusstvo, 1972, $440 \mathrm{p}$.

Latest Virtual Reality Technology Makes Opera Even More Magical. URL: http://www.bath.ac.uk/ research/news/2017/10/11/vr-opera/ [retrieved 8-Apr-2018]

MUNK, Nina. The Met's Grand Gamble. URL: https://www.vanityfair.com/culture/2010/05/metropolitan-opera-201005 [retrieved 6-Apr-2018]

Operabase. URL: http://operabase.com/index.cgi?lang=en [retrieved 2-Apr-2018]

The Marriage of Figaro Tweet Seats. Boston Lyric Opera. URL: http://info.blo.org/figaro-tweet [retreived 8-Apr-2018]

The Metropolitan Opera Annual report 2015/2016. URL: https://www.metopera.org/metoperafiles/ annual_reports/2016-17/AR1516.pdf [retrieved 6-Apr-2018]

TRAN, Diep. The Top 10 Most-Produced Plays of the 2014-15 Season. URL: https://www.americantheatre.org/2014/09/23/top-10-plays-2014-2015/ [retrieved 1-Apr-2018]

TRAN, Diep. The Top 10 Most-Produced Plays of the 2015-16 Season. URL: https://www.americantheatre.org/2015/09/16/the-top-10-most-produced-plays-of-the-2015-16-season/ [retrieved 1-Apr-2018]

TRAN, Diep. The Top 10 Most-Produced Plays of the 2017-18 Season. URL: https://www.americantheatre.org/2017/09/21/the-top-10-most-produced-plays-of-the-2017-18-season/ [retrieved 1-Apr-2018]

TRAN, Diep. The Top 10* Most-Produced Plays of the 2016-17. URL: https://www.americantheatre. org/2016/09/21/the-top-10-most-produced-plays-of-the-2016-17-season/ [retrieved 1-Apr-2018]

Tweet Seats. Opera Theatre of Saint Louis. URL: https://www.opera-stl.org/explore-and-learn/ for-everyone/2018-tweet-seats/ [retrieved 8-Apr-2018]

Tweet your way through the opera! Palm Beach Opera. URL: https://pbopera.org/currentseason/ tickets/tweet-seats/ [retrieved 8-Apr-2018] 


\section{Other sources:}

Deutsche Oper Berlin. URL: https://www.deutscheoperberlin.de/

Opera National de Paris. URL: https://www.operadeparis.fr/en

Prague National Theater. URL: https://www.narodni-divadlo.cz/en/state-opera

Royal Opera House. URL: http://www.roh.org.uk/

Teatro La Fenice. URL: http://www.teatrolafenice.it/site/index.php

The Bolshoi Theater. URL: https://www.bolshoi.ru/en/

The Metropolitan Opera. URL: https://www.metopera.org/

Wiener Staatsoper. URL: https://www.wiener-staatsoper.at/ 